\title{
Trianthema portulacastrum AND Cyperus rotundus INTERFERENCE IN Maize AND APplication of Allelopathic CROP EXTRACTS FOR THEIR EFfeCtive MANAGEMENT ${ }^{1}$
}

\author{
Interferência de Trianthema portulacastrum e Cyperus rotundus sobre o Milho e Manejo Eficaz \\ com a Aplicação de Extratos Alelopáticos à Cultura
}

\author{
NAEEM, M. ${ }^{2}$, MAHMOOD, A. ${ }^{2}$, IHSAN, M.Z. ${ }^{3}$, DAUR, $\mathrm{I} .^{3}$, HUSSAIN, S. ${ }^{4}$, ASLAM, $Z .^{2}$, and \\ ZAMANAN, S.A. ${ }^{3}$
}

\begin{abstract}
Horse purslane (Trianthema portulacastrum) and purple nutsedge (Cyperus rotundus) are two noxious $\mathrm{C} 4$ weeds of maize crop causing extensive yield losses. A two years field experiment was performed to estimate interference of $T$. portulacastrum and $C$. rotundus and to evaluate the role of allelopathic water extracts for effective weed management in maize. Five plant water extracts in ten binary combinations were foliar applied in triplicated randomized complete block design. Plots treated with commercial herbicide atrazine and weedy check (control), were also maintained for comparison. The highest density of both weed species was observed at 45 days after sowing (DAS) while weed dry biomass was higher at 60 DAS. Binary combination of sorghum-sunflower depicted greater suppression for weed density, dry biomass and persistence index $(88-92 \%$ for T. portulacastrum and $65-81 \%$ for C. rotundus) as compared with weedy check. This treatment combination has also recorded an enhancement of $125 \%$ in crop resistance index, $84 \%$ in leaf area index and $41 \%$ in crop growth rate at 60-75 DAS thus, leading to $51 \%$ improvement in grain yield. Binary combination of sunflower-brassica returned maximum marginal net benefit, while sorghum-maize combination anticipated the peak value for marginal rate of return. Along with the effective weed management and higher yield, sorghum-sunflower documented the maximum net economic benefits among different plant extract combinations therefore, suggesting that exogenous application of sorghum-sunflower extract can be effectively used for controlling these weeds in maize field.
\end{abstract}

Keywords: plant leachates, binary combination, allelochemicals, net benefits, weed management.

RESUMO - Bredo (Trianthema portulacastrum) e tiririca (Cyperus rotundus) são duas plantas daninhas do tipo $C 4$ que causam grandes perdas de rendimento na cultura do milho. Foi realizado um experimento de campo com duração de dois anos para estimar a interferência de T. portulacastrum $e$ C. rotundus e avaliar o potencial alelopático dos extratos aquosos no manejo eficaz de plantas daninhas no milho. Cinco extratos aquosos de espécies vegetais em dez combinações binárias foram aplicados nas folhas em um delineamento experimental de blocos casualizados, com três repetições. As parcelas foram tratadas com o herbicida comercial atrazina, e a testemunha sem capina (controle) foi utilizada para fins de comparação. A maior densidade de ambas as espécies de plantas daninhas foi observada 45 dias após a semeadura (DAS), enquanto a biomassa seca das plantas daninhas foi maior aos 60 DAS. A combinação binária de sorgo-girassol resultou na maior redução de densidade das plantas daninhas, biomassa seca e indice de persistência (88-92\% para T. portulacastrum e 65-81\% para C. rotundus) em comparação com a testemunha sem capina. Esta combinação de tratamento também registrou um aumento de $125 \%$ no indice de resistência da cultura, 84\% no indice de área foliar, $41 \%$ na taxa de crescimento da cultura aos 60-75 DAS, levando

Recebido para publicação em 18.10.2015 e aprovado em 18.11.2015.

Department of Agronomy, University of Agriculture Faisalabad, Pakistan; ${ }^{3}$ Department of Arid Land Agriculture, King Abdul Aziz University Jeddah, Saudi Arabia; ${ }^{4}$ College of Resources and Environment, Huazhong Agricultural University, Wuhan, Hubei 430070, China.<meeransaim@gmail.com>. 
assim, ao aumento de 51\% na produção de grãos. A combinação binária de girassol-colza resultou em máximo beneficio líquido marginal, enquanto a combinação milho-sorgo permitiu estimar o valor máximo da taxa marginal de retorno. Além do manejo eficaz de plantas daninhas e do maior rendimento, a combinação sorgo-girassol trouxe os melhores beneficios econômicos liquidos entre as diferentes combinações de extratos vegetais, sugerindo, portanto, que a aplicação exógena do extrato de sorgogirassol pode ser uma ferramenta eficaz no controle destas plantas daninhas em lavouras de milho.

Palavras-chave: lixiviados de plantas, combinação binária, aleloquímicos, benefícios líquidos, manejo de plantas daninhas.

\section{INTRODUCTION}

Maize (Zea mays) is one of the major cereal crops, cultivated both in irrigated and rain-fed areas. In Pakistan, maize is cultivated in an area of 1.12 million hectares with an average yield of 4.52 million tonnes (Mahmood et al., 2015). Current average yield of maize in Pakistan (4.05 tha-1) is far behind that of the world potential yield (12 $\left.\mathrm{t} \mathrm{ha}^{-1}\right)$. This yield gap may be ascribed to different environmental and management factors. Weed infestation is the major yield-reducing factor in maize crop (Fahad et al., 2014). Previously, Usman et al. (2001) have reported 83\% yield losses under uncontrolled weed infestation. The intensity of yield losses through weed infestation is dependent on type of weed species, density, time of emergence and duration of weed crop interference (Hussain et al., 2015). Additional to their competition for natural resources (air, space, water, nutrient, light), weeds were also reported for their toxic allelopathic interactions with plant roots through release of allelochemicals in the rhizosphere (Hussain et al., 2015). A grain yield loss of 58\% has been recently reported for unsatisfactory weed control in maize crops (Ihsan et al., 2015). Among major weeds of maize crops, desert horse purslane (Trianthema portulacastrum) and purple nutsedge (Cyperus rotundus) are reported for $80-90 \%$ (Aneja et al., 2000) and 23-89\% (Matloob et al., 2010) infestation under field conditions, respectively.

Out of seventy reported weeds in maize, T. portulacastrum and C. rotundus are the most problematic weeds in Pakistan. Both weeds are fast-growing and classified as $\mathrm{C} 4$, which makes them suitable to moist, dry, saline and waste land areas. T. portulacastrum was originated from South Africa and is distributed all over the world. Likewise, C. rotundus is also very common worldwide, especially in South East Asia, competing against 52 different crops in 92 countries in the tropical and subtropical regions of the world (Rao, 2000). In Pakistan, both of these weeds occur in major field crops of summer season, especially in pulses, cotton, sugarcane, direct seeded rice and maize (Matloob et al., 2010).

T. portulacastrum is a succulent, prostrate herb with ovate green leaves, annual life cycle and indeterminate growth habit (Fahad et al., 2014). Moreover, little seed dormancy, enormous seeding capacity and multiple generations in single season makes it highly unmanageable. Higher branching capacity and prostrate growth habits help it to quickly cover the ground and form a green carpet (Senthil et al., 2009). It produces numerous small, white flowers from April to October in Pakistan, and it has high fecundity. Flowering starts 20 to 30 days after emergence. A mature plant can produce as many as 3,330 fruits per plant and 6-10 seeds per fruit (Galinato et al., 1999). Leaf pattern/symmetry and stem structure of C. rotundus make it unique compared with other grasses, as it has narrow linear folded leaves with simple leaf blade without any collar along with a solid triangular stem. Tubers are the primary means of propagation for C. rotundus. The reproductive stage starts with chilling temperatures in the winter. High herbicide resistance, fast and intensive vegetative growth and re-sprouting capability makes it a more dangerous weed for most field crops.

However, due to deleterious effects of herbicides, alternate methods need to be explored for better weed management in all crops. Among all other options, allelopathy has been extensively reviewed in the last decades to explore the nature of the allelopathic effects 
of one plant on another (Putnam \& Duke, 1974). Therefore, an experiment has been designed to explore the phytotoxic potential of sorghum, sunflower, brassica, maize and rice water extracts for management of T. portulacastrum and C. rotundus, applied as binary combinations. Response of various crop growth and grain yield indices, as well as economic and regression analysis to estimate level of yield losses associated with both weeds, will also be part of the present study.

\section{MATERIALS AND METHOD}

\section{Site description}

Field experiments for seasons in two consecutive years were conducted at the Agronomic Research Area, University of Agriculture, Faisalabad $\left(31.25^{\circ} \mathrm{N}, 73.09^{\circ} \mathrm{E}\right.$, $184.5 \mathrm{~m}$ above sea level), where previous history of the field showed heavy weed infestation. The soil of experimental site is classified as an Aridisole, sandy clay loam by USDA classification and as an Yermosols by FAO criteria. It is comprised of Lyallpur Soil Series. The proportion of sand, silt and clay was $50.7 \%, 21.1 \%$ and $28.2 \%$, respectively. Total organic matter, total nitrogen, available phosphorus and potassium were $0.67,0.039 \%$, 9.74 and $170 \mathrm{mg} \mathrm{kg}^{-1}$. Soil $\mathrm{pH}, \mathrm{EC}$, bulk density and CEC were $8.1,0.78 \mathrm{dSm}^{-1}, 1.34 \mathrm{~g} \mathrm{CC}^{-1}$ and $4.2 \mathrm{cmol}_{\mathrm{c}} \mathrm{kg}^{-1}$ respectively.

\section{Treatments}

Plant water leachates were prepared by a locally manufactured machine using young fresh leaves and tender twigs collected from mature plants (Foidle et al., 2001; Yasmeen et al., 2013). Five plant water extracts (WEs), viz., Sorghum (Sorghum bicolor), Sunflower (Helianthus annuus), Brassica (Brassica napus), Rice (Oryza sativa) and Maize (Zea mays) were used in binary combinations. Atrazine (6-chloro-N-ethyl-N'-(1-methylethyl)1,3,5-triazine-2,4-diamine) application at the commercially recommended rate of $0.50 \mathrm{~kg}$ a.i. ha ${ }^{-1}$ and weedy check (control) were also performed for comparison. The experiment was performed in triplicate in a randomized complete block design with a net plot size of $8 \mathrm{~m} \times 3 \mathrm{~m}$. Plant combinations with weed suppressing ability were applied in the respective plots using a knapsack hand sprayer fitted with a T-Jet Nozzle. Table 1 shows details of the applied treatments.

\section{Crop husbandry}

The seedbed was prepared by first cultivating the soil with a disk plough and then with a tractor mounted cultivator twice followed by planking. The maize hybrid "P 30Y87" was sown on $10^{\text {th }}$ and $15^{\text {st }}$ of August in 2010 and 2011, respectively, in single rows with $70 \mathrm{~cm}$ spacing, with the aid of a dibbler, to sustain the plant population. The same experimental site was used for both years, where previous history showed massive weed invasion of several genera. The recommended rates of $150 \mathrm{~kg} \mathrm{~N}, 100 \mathrm{~kg} \mathrm{P}_{2} \mathrm{O}_{5}$ and $100 \mathrm{~kg} \mathrm{~K}_{2} \mathrm{O}$ of fertilizer were applied as basal dose with $1 / 3^{\text {rd }}$ of $N$, while the remaining nitrogen was applied in 2 splits, 25 days after sowing (DAS) and 55 DAS as top dressing. The first irrigation was applied 3 days after sowing, and subsequent irrigations were applied at one-week interval. The crops were manually harvested at physiological maturity and threshed for further analysis.

\section{Sampling techniques and observations}

Density and dry biomass of Trianthema portulacastrum and Cyperus rotundus were calculated at 30 DAS, 45 DAS and 60 DAS using two randomly selected quadrates $(50 \mathrm{~cm} \times 50 \mathrm{~cm})$ from each plot. Weed dry biomass was estimated by sun drying the samples for one weak, followed by oven drying at $70{ }^{\circ} \mathrm{C}$ until constant weight. Data on weed dry biomass and density was further used to compute some weed and crop efficiency indices against infested weeds and applied plant water extracts (Misra \& Misra, 1997).

Weed persistence index (WPI)):

$$
W P I=\frac{\text { Dry matter of weed in treated plot }}{\text { Drymatter of weed in control plot }} * \frac{\text { Weed count in control }}{\text { Weed count in treated plots }}
$$


Table 1 - Treatments adopted for management of Trianthema portulacastrum and Cyperus rotundus in maize

\begin{tabular}{|c|c|c|c|}
\hline № & Treatment & Description & Code \\
\hline $\mathrm{T} 1$ & Control & Natural weed infestation of all weeds, no weed control. & Control \\
\hline $\mathrm{T} 2$ & Atrazine & Atrazine herbicide @ 0.50 kg a.i. ha ${ }^{-1}$ foliar spray (early post-emergence) & Atr \\
\hline T3 & Sorghum-Sunflower & Aqueous extract of sorghum and sunflower each @15 L ha ${ }^{-1}$ foliar spray (20 DAS) & Sor-Sun \\
\hline T4 & Sorghum-Brassica & Aqueous extract of sorghum and brassica each@15 L ha ${ }^{-1}$ foliar spray (20 DAS) & Sor-Bra \\
\hline T5 & Sorghum-Maize & Aqueous extract of sorghum and maize each @15 L L ha ${ }^{-1}$ foliar spray (20 DAS) & Sor-Mai \\
\hline T6 & Sorghum-Rice & Aqueous extract of sorghum and rice each @ $15 \mathrm{~L} \mathrm{ha}^{-1}$ foliar spray (20 DAS) & Sor-Ric \\
\hline $\mathrm{T} 7$ & Sunflower-Brassica & Aqueous extract of sunflower and brassica each @ $15 \mathrm{~L} \mathrm{ha}^{-1}$ foliar spray (20 DAS) & Sun-Bra \\
\hline T8 & Sunflower-Maize & Aqueous extract of sunflower and maize each @15 L ha ${ }^{-1}$ foliar spray (20 DAS) & Sun-Mai \\
\hline T9 & Sunflower-Rice & Aqueous extract of sunflower and rice each @ $15 \mathrm{~L} \mathrm{ha}^{-1}$ foliar spray (20 DAS) & Sun-Ric \\
\hline $\mathrm{T} 10$ & Brassica-Maize & Aqueous extract of brassica and maize each @ $15 \mathrm{~L} \mathrm{ha}^{-1}$ foliar spray (20 DAS) & Bra-Mai \\
\hline T11 & Brassica-Rice & Aqueous extract of brassica and rice each @ $15 \mathrm{~L} \mathrm{ha}^{-1}$ foliar spray (20 DAS) & Bra-Ric \\
\hline T12 & Maize-Rice & Aqueous extract of maize and rice each @ $15 \mathrm{~L} \mathrm{ha}^{-1}$ foliar spray (20 DAS) & Mai-Ric \\
\hline
\end{tabular}

Crop resistance index (CRI):

$$
W P I=\frac{\text { Dry matter of crop in treated plot }}{\text { Drymatter of cropincontrol plot }} * \frac{\text { Dry matter of weedsincontrol plot }}{\text { Dry matter of weedsintreated plots }}
$$

Weed management index (WMI):

$$
W M I=\frac{\text { Percent } \text { yield over control }}{\text { Percent control of weeds }}
$$

Crop growth indices viz., leaf area index (LAI), dry matter accumulation (DMA) $\mathrm{g} \mathrm{m}^{-2}$ and crop growth rate $(\mathrm{CGR}) \mathrm{g} \mathrm{m}^{-2}$ day $^{-1}$ were calculated at 30, 45, 60, 75 and 90 DAS (Watson 1947; Hunt 1978). The same protocol was followed to estimate crop dry weight as used for weed samples. The threshed seeds were cleaned and grain yield was recorded and expressed as $\mathrm{kg} \mathrm{ha}^{-1}$.

\section{Estimation of interference and economic level of yield loss}

The effects of water extract combinations on density and biomass of $T$. portulacastrum and C. rotundus were recorded at 15 days interval. Grain yield at harvest was correlated to density of $T$. portulacastrum and $C$. rotundus by using a simple linear regression model. Total variable cost (Rupees; Rs.), marginal cost (Rs.), adjusted grain yield (10\% less grain yield) and marginal net benefit (Rs.) were used to calculate marginal rate of return \% (CIMMYT, 1988; Uygur et al. 1999).

Planta Daninha, Viçosa-MG, v. 34, n. 2, p. 209-218, 2016

$$
\begin{aligned}
& y=[H M+U M / O V * U F] \times(100) \\
& M R R \%=\frac{\text { Marginalbenefits }}{\text { Marginal costs }} \times(100)
\end{aligned}
$$

where, $y=\%$ yield loss associated with weed density; $H M=$ cost of herbicide/plant aqueous extract $\left(\mathrm{Rs} \mathrm{ha}^{-1}\right) ; U M=$ treatment application cost (Rs ha $\left.{ }^{-1}\right) ; O V=$ average of expected grain yield in weed free plots $\left(\mathrm{kg} \mathrm{ha}^{-1}\right)$ and $U F=$ grain price $\left(\mathrm{Rs} . \mathrm{kg}^{-1}\right)$; Total variable cost $=$ sum of the costs (both cost and opportunity costs) that vary for a particular treatment; Marginal cost = the increase in net benefit which can be obtained by changing from one production alternative to another; Marginal benefit $=$ the increase in variable cost which occurs by changing from one production alternative to another; Dominated treatment $(D)=$ treatment which has higher cost but lower net benefit, Rs. = Pakistani rupees".

\section{Statistical analysis}

Analysis of variance (ANOVA) was performed to validate variation among treatment means. Tukey's HSD test at $p \leq 0.05$ probability level was used to define differences 
among treatment means (Steel et al., 1997). Correlation of the data between different variables was established through SAS (8.1).

\section{RESULTS AND DISCUSSION}

\section{Weed dynamics and management indices}

Density and dry biomass of Trianthema portulacastrum were significantly higher than those of Cyprus rotundus in both treated and non-treated plots. Maximum weed density values for $T$. portulacastrum $\left(74.69 / 0.25 \mathrm{~m}^{2}\right)$ and C. rotundus $\left(20.30 / 0.25 \mathrm{~m}^{2}\right)$ were recorded at 45 DAS while dry biomass $(85.18$ and $31.06 \mathrm{~g} 0.25 \mathrm{~m}^{2}$, respectively) was the highest at 60 DAS (Table 2 and 3). In the second year of study, there was a higher number of each weed with greater dry biomass accumulation. Foliar application of allelopathic plants leachates in binary combinations has significantly $(p \leq 0.05)$ reduced weed density and dry biomass. Plant combinations with sorghum, sunflower and brassica leachates showed greater weed suppression and lower biomass accumulation in comparison to those combinations which contained maize and rice water extracts. The weed suppression ability of the applied allelopathic combinations was also dependent on length of crop growth period and developmental stage after application. The plots treated with binary combinations of Sor-Sun, Sor-Mai and Sun-Bra showed the highest weed control for T. portulacastrum (86-88\%) and C. rotundus (55-65\%) at 30 DAS. The water leachate combination of Sor-Mai effectively controlled weeds until 30 DAS while, combinations of Sor-Sun and Sun-Bra were effective until 60 DAS for weed suppression. The highest reduction in T. portulacastrum density (74\% and $77 \%)$ was associated with Sun-Bra for the first year and Sor-Sun for the second year at 60 DAS.

Application of plant extract combinations reduced the weed persistence index (WPI) compared with the non-treated control. The Sor-Sun extract combination presented the lowest value for WPI, which was non-significant with Sor-Ric. There was an improvement in the weed management index (WMI) and the crop resistance index (CRI) under foliar application of plant extracts,

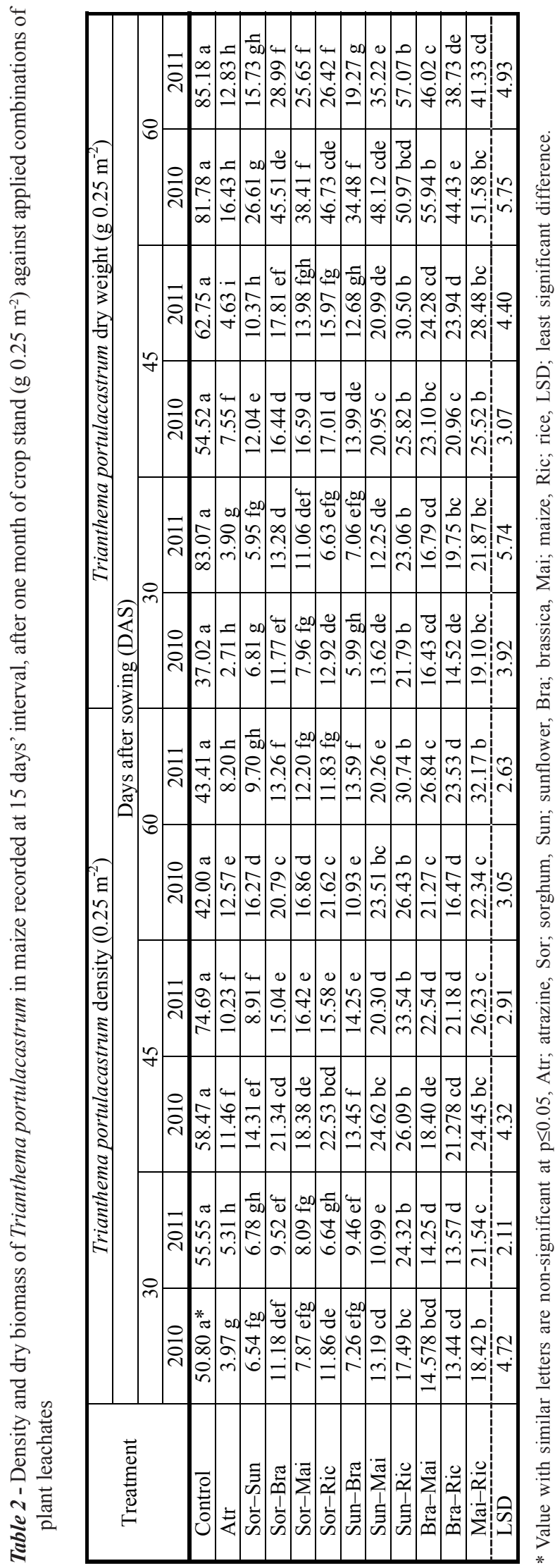

Planta Daninha, Viçosa-MG, v. 34, n. 2, p. 209-218, 2016 


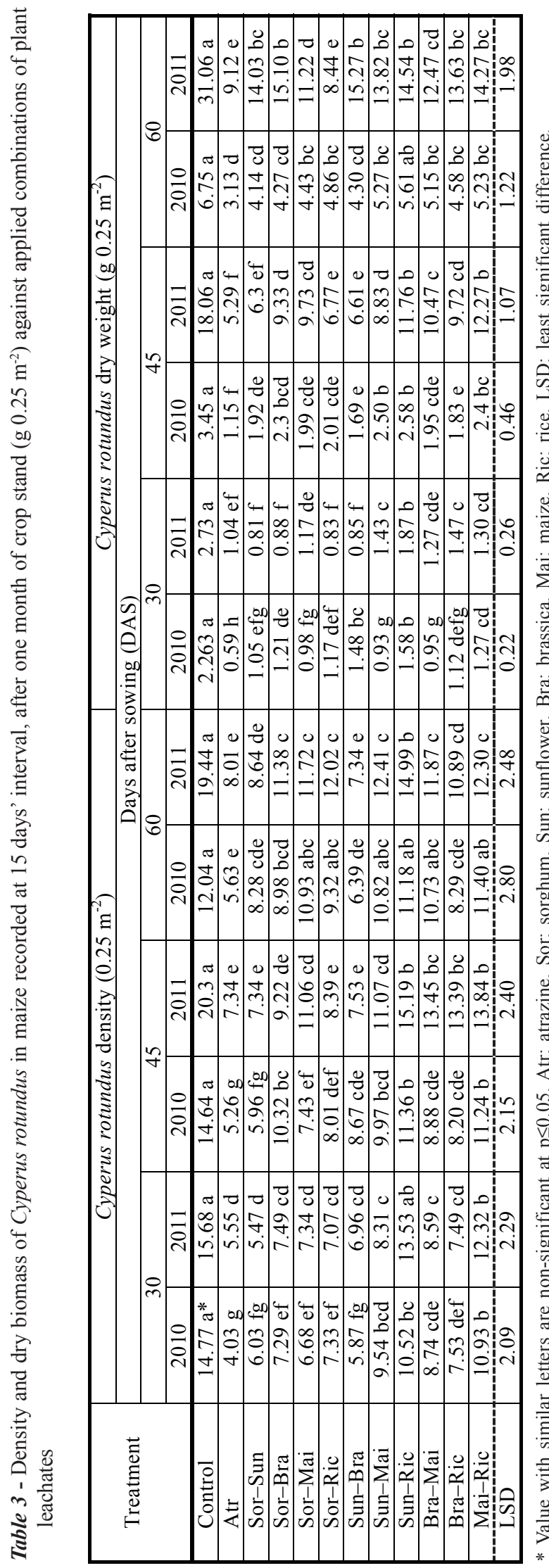

but it was non-significant with the commercial herbicide atrazine. Among plant leachates, Sor-Sun presented $201 \%$ and $160 \%$ and SunBra recorded $193 \%$ and $168 \%$ improvement in WMI throughout 2010 and 2011, respectively. Averaged across two years, Sun-Bra and Sor-Sun application improved the CRI by $125 \%$ and $89 \%$, respectively (Table 4).

\section{Maize growth indices and grain yield}

Crop growth indices viz., LAI, DMA and CGR recorded at a two-week interval showed significant variations under the influence of the applied plant extracts (Table 5). The maximum LAI and CGR were recorded at 60-75 DAS while DMA was the highest at maturity. Grain yield and crop growth indices showed $51-84 \%$ improvement under foliar application of different plant extracts. The plant combination Sor-Sun presented the maximum LAI, DMA and CGR (Table 5). The water extract combination of Sor-Sun reported $84 \%$ and $68 \%$ improvement in LAI and DMA while Sun-Bra resulted in $40 \%$ higher CGR as compared with the control. The highest grain yield was recorded for the Sor-Sun combination, which was 51\% higher.

\section{Correlation estimation and marginal analysis}

Correlation analysis revealed negative relationship of both weeds with maize grain yield. C. rotundus showed a stronger negative correlation compared with $T$. portulacastrum in both years (Figure 1). There was a strong positive correlation among different crop growth indices while both weeds presented negative association with crop growth indices. The effect of $C$. rotundus was more severe on DMA and CGR while T. portulacastrum recorded the highest negative correlation with LAI. Crop growth indices, especially CGR, showed the strongest positive correlation (0.977) with DMA while LAI also produced a positive association with DMA but moderately (Table 6). Correlation estimation, especially crop growth indices and grain yield, showed a strong negative correlation with both weed densities, thus urging the need for timely management.

The highest marginal cost was associated with chemical weed control, which resulted 
Table 4 - Interaction of various plant combinations for weed persistence index (WPI), weed management index (WMI) and crop resistance index (CRI) for two consecutive years

\begin{tabular}{|l|l|l|l|l|l|c|}
\hline \multirow{2}{*}{ Treatment } & \multicolumn{2}{|c|}{ WPI } & \multicolumn{2}{c|}{ WMI } & \multicolumn{2}{c|}{ CRI } \\
\cline { 2 - 7 } & 2010 & 2011 & 2010 & 2011 & 2010 & $17.25 \mathrm{~h}$ \\
\hline Control & $1.31 \mathrm{a}^{*}$ & $1.25 \mathrm{a}$ & $0.92 \mathrm{f}$ & $1.05 \mathrm{~g}$ & $15.59 \mathrm{i}$ & $54.97 \mathrm{~b}$ \\
\hline Atr & $0.45 \mathrm{f}$ & $0.77 \mathrm{~g}$ & $3.16 \mathrm{a}$ & $2.93 \mathrm{a}$ & $48.34 \mathrm{a}$ & $32.65 \mathrm{~b}$ \\
\hline Sor-Sun & $0.80 \mathrm{e}$ & $0.96 \mathrm{bcd}$ & $2.77 \mathrm{ab}$ & $2.74 \mathrm{abc}$ & $30.21 \mathrm{c}$ & $30.27 \mathrm{~cd}$ \\
\hline Sor-Bra & $1.13 \mathrm{~b}$ & $0.87 \mathrm{ef}$ & $2.69 \mathrm{ab}$ & $2.54 \mathrm{bcd}$ & $27.72 \mathrm{~d}$ & $30.79 \mathrm{c}$ \\
\hline Sor-Mai & $0.91 \mathrm{cde}$ & $0.92 \mathrm{cde}$ & $2.45 \mathrm{bcd}$ & $2.36 \mathrm{~d}$ & $24.51 \mathrm{e}$ & $32.55 \mathrm{~b}$ \\
\hline Sor-Ric & $1.02 \mathrm{bcd}$ & $0.80 \mathrm{fg}$ & $1.88 \mathrm{e}$ & $2.41 \mathrm{~d}$ & $20.01 \mathrm{fg}$ & $31.56 \mathrm{bc}$ \\
\hline Sun-Bra & $0.91 \mathrm{de}$ & $0.83 \mathrm{fg}$ & $2.70 \mathrm{ab}$ & $2.82 \mathrm{ab}$ & $35.14 \mathrm{~b}$ & $22.91 \mathrm{f}$ \\
\hline Sun-Mai & $0.89 \mathrm{de}$ & $1.01 \mathrm{~b}$ & $2.12 \mathrm{cde}$ & $2.41 \mathrm{~d}$ & $18.41 \mathrm{gh}$ & $20.61 \mathrm{~g}$ \\
\hline Sun-Ric & $0.96 \mathrm{bcde}$ & $0.81 \mathrm{fg}$ & $2.28 \mathrm{bcde}$ & $1.43 \mathrm{f}$ & $18.86 \mathrm{gh}$ & $26.00 \mathrm{e}$ \\
\hline Bra-Mai & $1.06 \mathrm{bcd}$ & $0.88 \mathrm{def}$ & $2.11 \mathrm{cde}$ & $2.49 \mathrm{~cd}$ & $29.05 \mathrm{~cd}$ & $29.03 \mathrm{~d}$ \\
\hline Bra-Ric & $0.90 \mathrm{de}$ & $0.84 \mathrm{efg}$ & $2.57 \mathrm{bc}$ & $2.66 \mathrm{abcd}$ & $20.63 \mathrm{f}$ & $17.49 \mathrm{~h}$ \\
\hline Mai-Ric & $1.09 \mathrm{bc}$ & $0.99 \mathrm{bc}$ & $1.98 \mathrm{de}$ & $2.03 \mathrm{e}$ & $17.45 \mathrm{~h}$ \\
\hline LSD & 0.18 & 0.13 & 0.50 & 0.32 & 1.70 & 1.13 \\
\hline
\end{tabular}

* Value with similar letters are non-significant at $\mathrm{p} \leq 0.05$, Atr; atrazine, Sor; sorghum, Sun; sunflower, Bra; brassica, Mai; maize, Ric; rice, LSD; least significant difference.

Table 5 - Maize growth indices and yield as affected by exogenously applied plant extracts in T. portulacastrum and C. rotundus infested plots

\begin{tabular}{|l|l|l|l|l|l|l|c|c|}
\hline \multirow{2}{*}{ Treatment } & \multicolumn{2}{|c|}{ Maximum LAI } & \multicolumn{2}{c|}{ Maximum DMA $\left(\mathrm{g} \mathrm{m}^{-2}\right)$} & \multicolumn{2}{c|}{ Mean CGR $\left(\mathrm{g} \mathrm{m}^{-2}\right.$ day $\left.^{-1}\right)$} & \multicolumn{2}{c|}{ Grain Yield $\left(\mathrm{t}\right.$ ha $\left.^{-1}\right)$} \\
\cline { 2 - 9 } & 2010 & 2011 & 2010 & 2011 & 2010 & 2011 & 2010 & 2011 \\
\hline Control & $2.65 \mathrm{~g}$ & $3.10 \mathrm{f}$ & $903.93 \mathrm{~g}$ & $791.24 \mathrm{~h}$ & $17.31 \mathrm{f}$ & $14.74 \mathrm{~d}$ & $3.77 \mathrm{~g}$ & $3.73 \mathrm{e}$ \\
\hline Atr & $5.09 \mathrm{a}$ & $4.71 \mathrm{a}$ & $1578.86 \mathrm{a}$ & $1434.47 \mathrm{a}$ & $25.32 \mathrm{a}$ & $21.39 \mathrm{a}$ & $6.33 \mathrm{a}$ & $6.23 \mathrm{a}$ \\
\hline Sor-Sun & $4.90 \mathrm{ab}$ & $4.70 \mathrm{a}$ & $1518.35 \mathrm{~b}$ & $1354.57 \mathrm{c}$ & $24.19 \mathrm{abc}$ & $20.56 \mathrm{ab}$ & $5.69 \mathrm{~b}$ & $5.60 \mathrm{ab}$ \\
\hline Sor-Bra & $4.69 \mathrm{bcd}$ & $4.55 \mathrm{ab}$ & $1265.60 \mathrm{e}$ & $1164.42 \mathrm{e}$ & $20.78 \mathrm{de}$ & $18.32 \mathrm{abc}$ & $5.11 \mathrm{~cd}$ & $4.58 \mathrm{~d}$ \\
\hline Sor-Mai & $4.74 \mathrm{bc}$ & $4.53 \mathrm{ab}$ & $1346.65 \mathrm{~d}$ & $1337.29 \mathrm{~cd}$ & $23.28 \mathrm{abcd}$ & $19.55 \mathrm{abc}$ & $5.44 \mathrm{bc}$ & $5.25 \mathrm{bc}$ \\
\hline Sor-Ric & $4.55 \mathrm{cde}$ & $4.40 \mathrm{bc}$ & $1429.29 \mathrm{c}$ & $1305.35 \mathrm{~d}$ & $21.92 \mathrm{bcde}$ & $19.55 \mathrm{abc}$ & $5.13 \mathrm{~cd}$ & $5.47 \mathrm{~b}$ \\
\hline Sun-Bra & $4.71 \mathrm{bc}$ & $4.50 \mathrm{~b}$ & $1457.13 \mathrm{c}$ & $1393.17 \mathrm{~b}$ & $24.42 \mathrm{ab}$ & $20.62 \mathrm{ab}$ & $5.45 \mathrm{bc}$ & $5.52 \mathrm{~b}$ \\
\hline Sun-Mai & $4.43 \mathrm{de}$ & $4.28 \mathrm{c}$ & $1208.06 \mathrm{e}$ & $1154.62 \mathrm{e}$ & $21.16 \mathrm{cde}$ & $17.79 \mathrm{bcd}$ & $4.92 \mathrm{de}$ & $4.69 \mathrm{~cd}$ \\
\hline Sun-Ric & $3.87 \mathrm{f}$ & $3.67 \mathrm{e}$ & $1100.21 \mathrm{f}$ & $1068.28 \mathrm{f}$ & $19.91 \mathrm{ef}$ & $16.90 \mathrm{~cd}$ & $4.54 \mathrm{ef}$ & $4.69 \mathrm{~cd}$ \\
\hline Bra-Mai & $4.29 \mathrm{e}$ & $4.01 \mathrm{~d}$ & $1326.63 \mathrm{~d}$ & $1304.59 \mathrm{~d}$ & $21.35 \mathrm{cde}$ & $18.99 \mathrm{abc}$ & $4.81 \mathrm{def}$ & $4.79 \mathrm{~cd}$ \\
\hline Bra-Ric & $4.54 \mathrm{cde}$ & $4.28 \mathrm{c}$ & $1484.53 \mathrm{bc}$ & $1318.02 \mathrm{~cd}$ & $20.60 \mathrm{de}$ & $19.48 \mathrm{abc}$ & $4.44 \mathrm{f}$ & $4.37 \mathrm{de}$ \\
\hline Mai-Ric & $3.71 \mathrm{f}$ & $3.49 \mathrm{e}$ & $1127.01 \mathrm{f}$ & $981.51 \mathrm{~g}$ & $19.72 \mathrm{ef}$ & $17.07 \mathrm{~cd}$ & $4.39 \mathrm{f}$ & $4.79 \mathrm{~cd}$ \\
\hline LSD & 0.28 & 0.19 & 57.58 & 37.21 & 3.07 & 3.44 & 0.47 & 0.65 \\
\hline
\end{tabular}

* Value with similar letters are non-significant at $\mathrm{p} \leq 0.05$, Atr; atrazine, Sor; sorghum, Sun; sunflower, Bra; brassica, Mai; maize, Ric; rice, LSD; least significant difference.

in the lowest marginal rate of return. The binary combination of Sun-Bra showed the highest marginal net benefit while the maximum value for marginal rate of return was reported for Sor-Mai. The highest level of yield loss was reported where the full dose of chemical herbicide was applied followed by Sor-Ric plant extracts applied as exogenous foliar spray. Overall results indicated that Sun-Bra combination was the best allelopathic combination for effective weed control and for net benefit (954 US\$ ha-1) (Table 6).
Cyperus rotundus and T. portulacastrum are the most pernicious weeds in maize fields of Pakistan. Management of both weeds is of prime importance for economical crop production. Complete crop failure has been reported under higher weed infestation in maize. Randhawa (2012) indicated that T. portulacastrum is the most problematic weed and a density of 5 plant $\mathrm{m}^{-2}$ recorded significant reductions in plant height, growth indices and grain yield. Allelopathic weed management is a fascinating and economical 

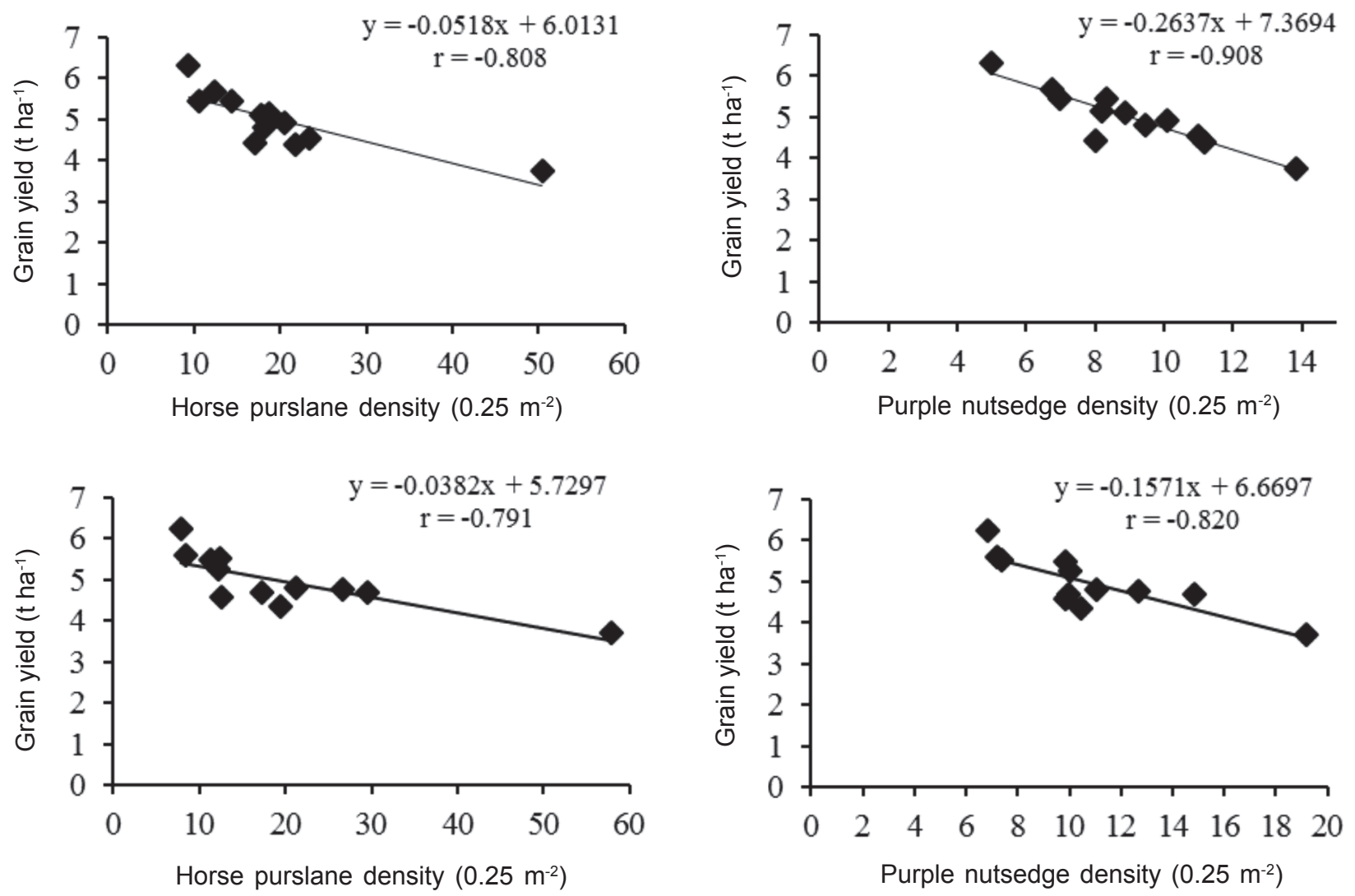

Figure 1 - Regression model predicting maize grain yield $\left(\mathrm{t} \mathrm{ha}^{-1}\right)$ as a function of horse purslane density $\left(0.25 \mathrm{~m}^{-2}\right)(\mathrm{A}$ and $\mathrm{C})$ and purple nutsedge density $\left(0.25 \mathrm{~m}^{-2}\right)(\mathrm{B}$ and $\mathrm{D})$ for two consecutive years under various weed management treatments.

Table 6 - Economic and marginal analysis for applied allelopathic treatments in comparison with chemical treatment

\begin{tabular}{|c|c|c|c|c|c|c|c|c|c|c|c|}
\hline \multirow[t]{2}{*}{ Treatment } & \multirow{2}{*}{$\begin{array}{c}\begin{array}{c}\text { Total } \\
\text { variable } \\
\text { cost }(\mathrm{Rs})\end{array} \\
2010-11 \\
\end{array}$} & \multirow{2}{*}{$\begin{array}{c}\begin{array}{c}\text { Marginal } \\
\text { costs } \\
(\mathrm{Rs})\end{array} \\
2010-11\end{array}$} & \multicolumn{2}{|c|}{$\begin{array}{c}\text { Adjusted grain } \\
\text { yield } \\
\mathrm{t} \mathrm{ha}^{-1}\end{array}$} & \multicolumn{2}{|c|}{$\begin{array}{l}\text { Net benefits } \\
\text { (Rs) }\end{array}$} & \multicolumn{2}{|c|}{$\begin{array}{l}\text { Marginal net } \\
\text { benefits (Rs) }\end{array}$} & \multicolumn{2}{|c|}{$\begin{array}{l}\text { Marginal rate of } \\
\text { return }(\%)\end{array}$} & \multirow{2}{*}{$\begin{array}{l}\text { Y (level } \\
\text { of yield) }\end{array}$} \\
\hline & & & 2010 & 2011 & 2010 & 2011 & 2010 & 2011 & 2010 & 2011 & \\
\hline Control & 0 & - & 3.40 & 3.36 & 60350 & 65520 & - & - & - & - & - \\
\hline Sun-Bra & 1540 & 1540 & 4.91 & 4.97 & 87153 & 96915 & 26803 & 31395 & 1740 & 2039 & 1.24 \\
\hline Sun-Mai & 1570 & 30 & 4.43 & 4.22 & 78633 & 82290 & 0 & 0 & $\mathrm{D}$ & $\mathrm{D}$ & 1.26 \\
\hline Bra-Mai & 1570 & 0 & 4.33 & 4.31 & 76858 & 84045 & 0 & 1755 & $\mathrm{D}$ & $\mathrm{D}$ & 1.26 \\
\hline Sun-Ric & 1590 & 20 & 4.09 & 4.22 & 72598 & 82290 & 0 & 0 & $\mathrm{D}$ & $\mathrm{D}$ & 1.28 \\
\hline Bra-Ric & 1590 & 0 & 4.00 & 3.93 & 71000 & 76635 & 0 & 0 & $\mathrm{D}$ & $\mathrm{D}$ & 1.28 \\
\hline Mai-Ric & 1620 & 30 & 3.95 & 4.31 & 70112 & 84045 & 0 & 7410 & $\mathrm{D}$ & 24700 & 1.30 \\
\hline Sor-Sun & 1690 & 70 & 5.12 & 5.04 & 90880 & 98280 & 20768 & 14235 & 29669 & 20336 & 1.36 \\
\hline Sor-Bra & 1690 & 0 & 4.60 & 4.12 & 81650 & 80340 & 0 & 0 & $\mathrm{D}$ & $\mathrm{D}$ & 1.36 \\
\hline Sor-Mai & 1720 & 30 & 4.90 & 4.73 & 86975 & 92235 & 5325 & 11895 & 17750 & 39650 & 1.38 \\
\hline Sor-Ric & 1740 & 20 & 4.62 & 4.92 & 82005 & 95940 & 0 & 3705 & $\mathrm{D}$ & 18525 & 1.40 \\
\hline Atr & 2050 & 310 & 5.70 & 5.61 & 101175 & 109395 & 19170 & 13455 & 6184 & 4340 & 1.65 \\
\hline
\end{tabular}

Variable cost $=$ Sum of the costs (both costs and opportunity costs) that vary for a particular treatment. Marginal costs $=$ Increase in net benefit which occurs by changing from one production alternative to another. Marginal benefits $=$ Increase in variable cost which occurs by changing from one production alternative to another. $\mathrm{D}=$ Dominated treatment $=$ Treatment which has higher costs but lower net benefits. Rs. = Rupees; WEs=Water extracts; DAS= Days after sowing.

Marginal rate of return $(\%)=\frac{\text { Marginal benefits }}{\text { Marginal cost }} \times 100$ 
option; it has potential for adaptability with significant results. In the present experiment, all plant leachate combinations presented remarkable reduction in weed dynamics. This reduction was variable in accordance with the compatibility of the plants used in the study. The binary combinations with sorghum, brassica and sunflower water leachates as their complementary parts resulted in the highest suppression in weed density and dry biomass as well as significant improvement in final grain yield. The allelopathic potential of these plants has already been reported as a single application or in combination with reduced dose of different herbicides (Cheema et al., 2002). Improved weed control is due to presence of multiple secondary metabolites that are released into the environment through volatilization, leaching and decomposition. The phytotoxic potential of sorghum was documented by Putnam et al. (1983). A field evaluation of sorghum leachates was reported later on by isolating nine allelochemicals that are biologically active against some important weeds such as Chenopodium album, Phalaris minor and Cyperus rotundus. This phytotoxicity is due to the presence of a number of allelochemicals including gallic acid in sorghum (Netzly \& Butler, 1986), chlorogenic acid in sunflower (Macias et al., 2002) and glucosinolates in brassica (Velasco et al., 2008).

Both stimulatory and inhibitory effects of allelochemicals have been reported in the past. It is strongly believed that these effects are concentration-dependent as the 25\% concentration of sunflower leachate stimulated weed growth in wheat while the 100\% concentration resulted in more than $80 \%$ weed suppression (Nikneshan et al., 2011). Allelochemicals damage the antioxidant system of target plants through cell membrane permeability, cellular damage, inhibition of photosystem and hormonal activities (Oracz et al., 2007). There was up to $66 \%$ reduction in $T$. portulacastrum seedling under higher concentration of these leachates (Mahmood et al., 2010). Higher weed suppression with binary combination of different aqueous extracts might be associated with probability of synergistic effect of these plants (Duke, 2010). For the single application of sorghum extract, only $28 \%$ weed suppression has been reported (Cheema et al., 2002) while there was more than $70 \%$ weed suppression by mixing sorghum, sunflower and eucalyptus water extracts (Cheema et al., 2003). The greater suppression of $T$. portulacastrum in those plots, where combination of sorghum leachates were foliar applied, might have been due to the selective nature of sorghum extracts and T. portulacastrum susceptibility against sorghum. Mahmood et al. (2010) have reported up to $95 \%$ weed inhibition and $66 \%$ plant dry weight reduction at 100\% leachate concentration.

Under the changing scenario of increasing environmental pollution and issues of herbicidal resistance development, allelopathic weed management can be a suitable possible alternative. All plant combinations considerably reduced density and dry biomass accumulation of Trianthema portulacastrum and Cyperus rotundus and improved maize growth indices and grain yield. Water extracts of sorghumsunflower outperformed all other plant extract combinations and recorded significant weed suppression. This treatment combination has also resulted in the highest yield and net economic benefits, suggesting that exogenous application of sorghum-sunflower extract can be effectively used for controlling Trianthema portulacastrum and Cyperus rotundus.

\section{LITERATURE CITED}

ANEJA, K. R. et al. Management of horse purslane (Trianthema portulacastrum L.) with Gibbago trianthemae Simmons in India. In: INTERNATIONAL SYMPOSIUM ON BIOLOGICAL CONTROL OF WEEDS, 10., 2000. Proceeding of the 10th Intl. Symposium, Bozeman, Montana, U.S.A: Montana State University, 2000. p. 4-14.

CHEEMA, Z. A. et al. Reducing herbicide rate in combination with allelopathic sorgaab for weed control in cotton. Int. J.

Agric. Biol., v. 5, n. 1, p. 1-6. 2003.

CHEEMA, Z. A. et al. Response of wheat varieties and some rabi weeds to allelopathic effects of sorghum water extract. Int. J. Agric. Biol., v. 4, n. 1, p. 52-55, 2002.

CIMMYT. From agronomic data to farmer recommendations: an economics training manual. Mexico, DF: 1988. 27 p.

DUKE, S. O. Allelopathy: current status of research and future of the discipline: a commentary. Allelopathy J., v. 25, n. 1, p. 17-30, 2010. 
FAHAD, S. et al. Consequences of narrow crop row spacing and delayed Echinochloa colona and Trianthema portulacastrum emergence for weed growth and crop yield loss in maize. Weed Res., v. 54. n. 5, p. 475-483, 2014.

FOIDLE, N. et al. The potential of Moringa oleifera for agricultural and industrial uses. In: FUGILE, L. (Ed). The miracle tree: the multipurpose attributes of Moringa. Dordrecht: CTA Publications Wageningen, 2001. p. 45-76.

GALINATO, M. I.; MOODY, K.; PIGGIN, C. M. Upland rice weeds of south and southeast Asia. Makati City, Philippines: International Rice Research Institute, 1999. $156 \mathrm{p}$.

HUNT, R. Plant growth analysis. London: Edward Arnold, 1978. p. 8-38. (The Institute of Biology's Studiesin Biology, 96)

HUSAIN, S. et al. Interference and economic threshold level of little seed canary grass in wheat under different sowing times. Environ. Sci. Poll. Res., v. 22, n. 2, p. 441-449, 2015.

IHSAN, M. Z. et al. Field evaluation of allelopathic plant extracts alongside herbicides on weed management indices and weed-crop regression analysis in maize. Weed Biol.

Manage., v. 33, n. 1, p. 78-83, 2015.

MACIAS, F. et al. Allelochemials from sunflowers: chemistry, bioactivity and applications. In: INDERJIT, P. AND MALLIK, A. U. (Ed.). Chemical ecology of plants: allelopathy in aquatic and terrestrial ecosystems. Basel: Birkhauser Verlag, 2002. p. 73-87.

MAHMOOD, A. et al. Estimation of weed dry biomass and grain yield as a function of growth and yield traits under allelopathic weed management in

maize. Planta Daninha, v. 33, n. 1, p. 23-31, 2015.

MAHMOOD, A. et al. Evaluating the potential of allelopathic plant water extracts in suppressing horse purslane growth. Int. J. Agric. Biol., v. 12, n. 4, p. 581-585, 2010 .

MATLOOB, A. et al. Quantification of allelopathic potential of different crop residues for the purple nutsedge suppression. Pak J. Weed Sci. Res., v. 16, n. 1, p. 1-12, 2010 .

MISRA, M.; MISRA, A. Estimation of IPM index in jute: a new approach. Ind. J. Weed Sci., v. 29, n. 1, p. 39-42, 1997.

NETZLY, D. H.; BUTLER, L. G. Roots of sorghum exude hydrophobic droplets containing biologically active components. Crop Sci., v. 26, n. 4, p. 776-778, 1986.
NIKNESHAN, P. et al. Allelopathic potential of sunflower on weed management in safflower and wheat. Austr J. Crop Sci., v. 5, n. 11, p. 14-34, 2011.

ORACZ, K. et al. Induction of oxidative stress by sunflower phytotoxins in germinating mustard seeds. J. Chem. Ecol., v. 33, n. 2, p. 251-264, 2007.

PUTNAM A. R. et al. Exploitation of allelopathy for weed control in annual and perennial cropping systems. J. Chem. Ecol., v. 9, n. 1, p. 101-111, 1983.

PUTNAM, A. R.; DUKE, W. O. Biological suppression of weeds: Evidence for allelopathy in accessions of cucumber. Science, v. 185, n. 4, p. 370-372, 1974.

RANDHAWA, M. A. Studies into infestation of Trianthema portulacastrum (horse perslane) on the growth and quality behaviour of maize crop. Pak. J. Agri. Sci., v. 49, n. 1, p. 101-104, 2012.

RAO, V. S. Principles of weed science. (2nd Edn), 2000. $72 \mathrm{p}$.

SENTHIL, A. et al. Identification of threshold level of horse purslane (Trianthema portulacastrum) in irrigated cowpea (Vigna unguiculata). Indian J. Crop Sci., v. 4, n. 1, p. 141-143, 2009.

STEEL, R. G. D. et al. Principles and procedures of statistics: a biometrical approach. 3.ed. Columbus: McGraw Hill Book, 1997. p. 172-177.

USMAN, A. et al. Effect of weed interference and nitrogen on yields of a maize/rice intercrop. Int. J. Pest Manage., v. 47, n. 4, p. 241-246, 2001.

UYGUR, F. N. et al. Economic threshold of weeds and application in the world and Turkey. Bitki Korumada Ekonomik Zarar Esigi Modelleri ve Uygulamas. In: WORKSHOP, SAMSUN, September 8-9, 1999, Workshop... Turkey: 1999. p. 170-225.

VELASCO, P. et al. Comparison of glucosinolate profiles in leaf and seed tissues of different Brassica napuscrops. J. Am. Soc. Hortic. Sci., v. 133, n. 4, p. 551-558, 2008.

WATSON, D. J. Comparative physiological studies on the growth of field crops: II. The effect of varying nutrient supply on net assimilation rate and leaf area. Ann. Bot., v. 11, n. 3, p. $375-407,1947$.

YASMEEN, A. et al. Exogenous application of moringa leaf extract modulates the antioxidant enzyme system to improve wheat performance under saline conditions. Plant Growth Regul., v. 69, n. 3, p. 225-233, 2013. 